\title{
URBAN SPRAWL AND CONSEQUENCES OF POORLY MANAGED EXPANSION: THE CASE OF SÃO PAULO IN BRAZIL
}

\author{
Expansão Urbana e Consequências da Expansão Mal Gerenciada: \\ O Caso de São Paulo no Brasil
}

\author{
João Almeida Santos, Maria Cristina Sanches Amorim, \\ Arnoldo Jose de Hoyos Guevara \\ School of Management, Pontifical Catholic University of São Paulo, São Paulo, Brazil \\ E-mail: professoralmeida@ig.com.br, cris.amorim@pucsp.br, \\ arnoldodehoyos@yahoo.com.br
}

\begin{abstract}
Urban sprawl is a natural process of the cities' growth as consequence population growth. The population need a food, water and housing for survival and for its species to continue populating the land. The literature existing about urban sprawl considers a population growth causes impacts on people's quality of life because they consume more food, water, electricity, transport for their locomotion, and other products and services. The fact is the urban sprawl and population growth are directly linked and can not be separated in any study on the subject. Sprawl is the process in which the spread of development across the landscape far outpaces population growth. This is article show the process Urban sprawl and consequences of poorly managed expansion the city São Paulo - Brazil. The phenomenon of sprawl there are several common characteristics pervading time in history from development the city of São Paulo. The phenomenon of sprawl the city of São Paulo is a common the any big city, the result of a complex set of interrelated socioeconomic and cultural forces. For example, land value is often considered the main driver of socioeconomic development patterns. However, at any time in the current or ancient history, land value is lower on the periphery and very expensive in urban centers. Other factors contribute to the occupation of land on the outskirts of large cities: existence of water and the quality of land for agriculture, the cost of keeping the dwelling lower when compared to the cost of the city center, the size of the land is larger at the beginning of the occupation.
\end{abstract}

Keywords: Urban sprawl; Land; Urban centers; São Paulo City.

Resumo: A expansão urbana é um processo natural do crescimento das cidades como consequência do crescimento populacional. A população precisa de comida, água e moradia para sobrevivência e para que possa continuem a povoar a terra. A literatura existente sobre a expansão urbana considera que o crescimento populacional causa impactos na qualidade de vida das pessoas, pois elas consomem mais alimentos, água, eletricidade, transporte para sua locomoção e outros produtos e serviços. O fato é que a expansão urbana e o crescimento populacional estão diretamente ligados, e não podem ser separados em nenhum estudo sobre o assunto. Expansão é o processo no qual a disseminação do desenvolvimento em toda a paisagem ultrapassa de longe o crescimento da população. Neste trabalho se mostra em particular o processo Expansão urbana e consequências da expansão mal administrada da cidade de São Paulo - Brasil. No fenômeno da expansão existem várias características comuns que perpassam o tempo na história do desenvolvimento da cidade de São Paulo. O fenômeno da expansão da cidade de São Paulo é comum em qualquer grande cidade, resultado de um conjunto complexo de forças socioeconômicas e culturais inter-relacionadas. Por exemplo, o valor da terra é frequentemente considerado o principal impulsionador dos padrões de desenvolvimento socioeconômico. No entanto, a qualquer momento na história atual ou antiga, o valor da terra é menor na periferia e muito caro nos centros urbanos. Outros fatores contribuem para a ocupação da terra na periferia das grandes cidades: existência de água e qualidade da terra para a agricultura, o custo de manter a habitação menor quando comparado ao custo do centro da cidade, o tamanho da terra é maior no início da ocupação

Palavras-chave: Expansão urbana; Terra; Centros urbanos; Cidade de são Paulo.

\section{Recebido em: 24/08/2017}

Aceito em: 01/06/2018 


\section{INTRODUCTION}

Researchers concerned with rapid urban sprawl around large cities and within large urban centers began their studies after 1970(Torrens and Alberti, 2000; Nechyba and Walsh, 2004). Usage of the term sprawl was coined in 1937 by Earle Sumner Draper (1893-1994) one of the first city planners and a landscape designer in the southeastern United States (Nechyba and Walsh, 2004). Sprawl is the process in which the spread of development across the landscape far outpaces population growth. This is article show the process Urban sprawl and consequences of poorly managed expansion the city São Paulo - Brazil. The phenomenon of sprawl there are several common characteristics pervading time in history from development the city of São Paulo. The phenomenon of sprawl the city of São Paulo is a common the any big city, the result of a complex set of interrelated socioeconomic and cultural forces.

The common characteristics of the process of urban expansion of large cities are: cost of the land, water resource available for agriculture, means or mode of transport between the urban center and the new occupied region, communication by telephone or other existing means, etc.

For the occupation of a new region to succeed, it is necessary to have a road and a mode of transportation, among other things. When people decide to occupy other parts of a territory they need a road to transport the products they need and if they are producers in the new land, they should take the product to the consumer center that is the center of the city. Sprawled areas of the city are generally over-reliant on the automobile for access to resources and community facilities (Torrens and Alberti, 2000).

At the beginning of civilization, the occupation of new lands happened naturally and without any concern with planning or studies to determine the best way to occupy a region. Forests were felled to give space for the construction of houses that were erected with the wood of the trees that were felled.

The evolution of society and the great discoveries of the Industrial Revolution (1760 - 1840), for example, accelerate the process of urban spreading. Scientific discoveries to the reduction of contagious disease problems and increased food production have also been important contributors to population growth and the advancement of the urban sprawl process.

With the growth of the population and the concentration in small space, many problems arise, being an opportunity for researchers. Among the common points pointed out in the literature, the demographic growth demands construction of new residential, commercial, utility, and transport infrastructures. The conversion of forest and farmlands to give space to new residents seems to be an endless process (Rahman, 2016).

\section{URBAN SPRAWL}

The concept of urban sprawl emerged with the term Sprawl or Sprawl urban is relatively a form of wastage of urbanization, characterized by low densities and little uniformity in occupation. It is an uncoordinated action and extends along the edges of metropolitan areas in an accelerated way (Torrens and Alberti, 2000).

Urban sprawl invades agricultural areas and other areas that have indispensable water resources, such as springs. The occupation process is fragmented slowly and with repetition, it is consolidated in an urban spot. 
The problem is when this spreading leaves an intermediate space vacant or with little functionality between the occupation and the central area of the region.

The negative externalities that arise with urban expansion is a serious problem because of its strong association with numerous social problems, including marginality, even for metropolitan regions that are relatively compact in terms of occupation (Ewing, Pendall, Chen, 2000).

Understanding the causes, consequences, and policy implications related to expansion can provide important information on how to build more sustainable communities in the long run. In short, the low density of development can identify this spreading and the housing, the shopping center and the workplace are distant from each other. In general, they are deficient in transport and other infrastructure resources such as water and sewage, with a clear focus on urban centers that arise with the concept of downtown that serve as a point of reference and solution of people's needs (Ewing; Pendall and Chen, 2000).

Studies on the theme of urban sprawl or urban sprawl consider a monocentric city - when all decisions and the greatest amount of resources are concentrated in one place. The distance between the urban center and the place of production or housing activities has an impact on the final cost and must be considered in the decision to occupy a particular place. In von Thünen's studies (1826) it was shown that the cost of transport was passed on to the final price and the value of the land was greater for those who were close to the central market.

Table 1 Profile of Landscape Sprawl

\begin{tabular}{|c|c|}
\hline Profile & Meaning \\
\hline population dispersed & a population that is widely dispersed in low-density development. \\
\hline Shops and separate houses & $\begin{array}{l}\text { Rigidly separated homes, shops, and workplaces by distance that requires the use } \\
\text { of an increasing transport network. }\end{array}$ \\
\hline poor access & a network of roads marked by huge blocks and poor access. \\
\hline $\begin{array}{l}\text { downtowns and town } \\
\text { centers poor }\end{array}$ & $\begin{array}{l}\text { a lack of well-defined, thriving activity centers, such as downtowns and town } \\
\text { centers. }\end{array}$ \\
\hline $\begin{array}{l}\text { the lack of transportation } \\
\text { choices }\end{array}$ & $\begin{array}{l}\text { With the lack of planning for the occupation of regions on the outskirts of cities } \\
\text { and the lack of interest of urban planners to meet the needs of new residents, only } \\
\text { one transportation option is offered. }\end{array}$ \\
\hline $\begin{array}{l}\text { relative uniformity of } \\
\text { housing options }\end{array}$ & $\begin{array}{l}\text { The buildings and housing are not uniform because population has moved because } \\
\text { of the costs in the large centers and has no income to spend on the quality of } \\
\text { housing. }\end{array}$ \\
\hline the difficulty of walking & $\begin{array}{l}\text { The occupation without criterion or planning rule for the constructions that occupy } \\
\text { all possible spaces, leaves no room for the creation of sidewalks for the population } \\
\text { to walk. }\end{array}$ \\
\hline
\end{tabular}

Source: Ewing; Pendall and Chen, 2000:3.

In this sense, early studies to incorporate transport costs into the value of land and the costs of families to produce away from a large center was made by Johann von Thünen in 1826. The model developed by him admitted that the value of land varied according to the access to a central market, having no importance the soil fertility that he considered to be the same anywhere in Germany, where the study was done. When the producer sent the final product to the market, this distance that required more or less transport time made the final cost high and consequently the price of the agricultural product in that market should compensate for this cost increase (Matos, 2005).

However, sprawl as the process in which the spread of development across the landscape far outpaces population growth (Ewing, Pendall and Chen, 2000). 
During the process of urban sprawl, the city has space and supports population growth, increased construction for commerce and housing; without major problems with this agglomeration or conflict among the different types of inhabitants. The population growth and construction in a limited space, quickly leaves problems more evident. In the current context, large cities adopt measures to reduce the number of people and cars in circulation not only in large centers but also in smaller centers.

\section{SPRAWL URBAN AND QUALITY OF LIFE}

The process of sprawl urban happens because people want a place to live, produce food or goods. In occupied and developed urban centers, the cost for this achievement is very high. So, to reduce the cost of maintenance to have your home or place of production, people move away from large centers.

The increase in distance between the periphery and the city center represented by the cost of transportation. So the further away the new inhabitant build his home of the center, the greater will be his expense with transportation. In von Thünen's studies (1826) it was shown that the cost of transport was passed on to the final price.

The immediate reflection of this distance is in the budget of the individual and the other is in the quality of life. The people living in more sprawling regions tend to drive greater distances, own more cars, breathe more polluted air, and face to greater risk of traffic fatalities, difficulty for walking for lack of sidewalks and slow transit (Ewing, Pendall and Chen, 2000)

\section{Table 2 The Impacts of Sprawl Found in Research Measuring Sprawl and Its Impact (2000)}

\begin{tabular}{|c|c|}
\hline Impact & Result \\
\hline $\begin{array}{l}\text { Higher rates of driving and vehicle } \\
\text { ownership }\end{array}$ & $\begin{array}{l}\text { The research indicates that in relatively sprawling regions, the cars are } \\
\text { driven longer distances per person than in places with } \\
\text { lower-than-average sprawl. Also, adds up to millions of extra miles and } \\
\text { tons of additional vehicle emissions. Adds up pollution and respiration } \\
\text { bad. There are on average } 180 \text { cars to every } 100 \text { households. }\end{array}$ \\
\hline Increased levels of pollution & $\begin{array}{l}\text { Federal health-based standards are not met because the volume of } \\
\text { pollution generated is very high. The number of vehicles circulating, } \\
\text { factory chimneys, air conditioners; are some of the sources of this } \\
\text { pollution. Failing to reach the standard not only imperils the health of } \\
\text { children and other vulnerable populations, but also subjects regions to a } \\
\text { raft of rigorous compliance measures. }\end{array}$ \\
\hline Greater risk of fatal crashes & $\begin{array}{l}\text { Residents of more sprawling areas are at greater risk of dying in a car } \\
\text { crash. In the nation's most sprawling region, Riverside CA, } 18 \text { of every } \\
100,000 \text { residents die each year in traffic crashes. The higher death rates } \\
\text { in more sprawling areas may be related to higher amounts of driving, or } \\
\text { to more driving on high-speed arterials and highways, as opposed to } \\
\text { driving on smaller city streets where speeds are lower. }\end{array}$ \\
\hline $\begin{array}{l}\text { Depressed rates of walking and } \\
\text { alternative transport use }\end{array}$ & $\begin{array}{l}\text { In more sprawling places, people on their way to work are far less } \\
\text { likely to take the bus or train or to walk. Likewise, thousands more } \\
\text { residents walk to work in regions that sprawl less. }\end{array}$ \\
\hline
\end{tabular}

Source: Ewing, Pendall and Chen in Research Measuring Sprawl and Its Impact (2000) 
This study - Measuring Sprawl and Its Impact (2000)-show the sprawl phenomenon and analyze related impacts, noting that is important metropolitan areas debate the costs and consequences of poorly managed expansion. The authors propose that Politicians and planners aiming to contain sprawl also must have an agreed-upon way to define and measure it in order to track their progress. However, they should demonstrate how, and to what degree, sprawl has real implications for real people. ${ }^{1}$

The research in ten cities as Raleigh-Durham, NC, Atlanta, GA, West Palm Beach-Boca RatonDelray Beach, FL, Oxnard-Ventura, CA; showed that the consequences of the expansion were similar to those of other major cities in the world, such as the City of São Paulo - Brazil (table 2).

The urban sprawl and quality of life are in the opposite direction. While urban sprawl increases, with people concentrating on small spaces, the quality of life is worsened because of the impacts on transportation, air quality, increased respiratory diseases, a greater number of traffic accidents, among others.

Other a recent study of 75 U.S. urban areas finds that the total increase in commuting costs from congestion in these areas is $\$ 69.5$ billion, an average of $\$ 520$ per person. Of these costs, $\$ 60$ billion are attributed to the time costs associated with longer commute times, and $\$ 9.5$ billion are attributed to increased fuel consumption resulting from congestion-induced drops in fuel efficiency (Nechyba and Walsh, 2004).

The impact on production resources is a reality. In many regions of the world, water scarcity is a problem caused by the concentration of people and the indiscriminate use and control of people, inadequate construction that waterproof the soil and do not allow rainwater to penetrate underground or absence of governance policy on water use.

Table 3 Population Density - Ranks (people per sq. km of land area)

\begin{tabular}{|c|c|c|c|c|c|c|c|c|c|}
\hline Country & 2014 & 2011 & 2010 & 2009 & Country & 2014 & 2011 & 2010 & 2009 \\
\hline $\begin{array}{c}\text { Macao SAR, } \\
\text { China }\end{array}$ & 19073,1 & 18283,7 & 18000,9 & 17674,7 & Mauritius & 621,1 & 616,9 & 616,0 & 614,5 \\
\hline Monaco & 18811,5 & 18594,5 & 18422,5 & 18175,5 & San Marino & 526,6 & 515,6 & 511,5 & 507,2 \\
\hline Singapore & 7736,5 & 7363,2 & 7231,8 & 7125,1 & Korea, Rep. & 517,3 & 512,0 & 508,2 & 506,5 \\
\hline $\begin{array}{l}\text { Hong Kong } \\
\text { SAR, China }\end{array}$ & 6896,9 & 6734,9 & 6689,7 & 6640,8 & Netherlands & 500,9 & 495,0 & 492,6 & 490,1 \\
\hline Bahrain & 1768,7 & 1702,8 & 1655,3 & 1574,7 & Rwanda & 459,7 & 427,9 & 417,3 & 406,3 \\
\hline Maldives & 1336,7 & 1256,7 & 1223,3 & 1200,0 & Lebanon & 444,5 & 429,0 & 424,0 & 408,8 \\
\hline Malta & 1335,5 & 1300,8 & 1295,3 & 1289,0 & India & 435,7 & 419,6 & 414,0 & 408,4 \\
\hline Bangladesh & 1222,1 & 1178,5 & 1164,8 & 1151,6 & Burundi & 421,2 & 381,2 & 368,4 & 355,8 \\
\hline $\begin{array}{l}\text { West Bank } \\
\text { and Gaza }\end{array}$ & 713,4 & 652,3 & 633,1 & 615,0 & Comoros & 413,8 & 384,7 & 375,4 & 366,4 \\
\hline Barbados & 659,0 & 652,6 & 650,2 & 647,6 & Haiti & 383,6 & 368,1 & 362,8 & 357,5 \\
\hline
\end{tabular}

Source: https://knoema.com/search?query=Population $\% 20$ density

${ }^{1}$ URBANIZATION. UNFPA-United Nations Population Fund[M]. http://www.unfpa.org/urbanization1 
Many of these people will live in urban areas and the pressure on the cost of land, traffic, air pollution, traffic accidents and other problems mentioned in this article will be much larger. With the larger dimension of the problem, other costs will be part of society's budget, for example, costs of hospitals where injured people Will be treated or those with respiratory problems caused by air pollution in the city. The population is growing worldwide and can achieve a total of 10 billion people in 2050 .

Population growth causes an urban concentration because people need work, goods, and services. As shown by the table data (table 3), the high population density is determinant for people to look for new areas to be occupied, keeping the phenomenon of urban sprawl in the current moment.

The city of Macau in China has a territory of $30.3 \mathrm{sq} . \mathrm{km}$, i.e. little land space for many people, according to the Table 3. Data the population density in 2009 was 17.675 people per sq. $\mathrm{km}$, rising to 19.073 people in 2014 with growth trend.

In Burindi country, the size of its limited territory to 27.830 square kilometers and a population density of 421 people per square kilometer aggravate the problem. This represents a total of 10,816,860 inhabitants in 2014 and $11.8 \%$ were urban population. The increase in urban population is inevitable.

\section{METROPOLITAN AREA OF SÃO PAULO (MRSP)}

São Paulo is the most populous city in Brazil, located in the southeast region, earth's 12th largest city proper by population. The city is the capital of the homonymous state of São Paulo, Brazil's most populous and wealthiest state. Also, exerts strong international influence in commerce, finance, arts and entertainment.

The city's metropolitan area of Greater São Paulo ranks as the most populous in Brazil, the 11 th most populous on Earth. The Metropolitan Area of São Paulo (MRSP) is made up of 39 municipalities and in 2005 it had 19 million inhabitants and in 2014 reached a total of $20,935,204$ inhabitants representing $10.32 \%$ of the total population of Brazil.

At the time the state of São Paulo had 44,035,304 inhabitants and MRSP (Metropolitan Area of São Paulo) represented almost $48 \%$ of the total population, which gives an idea of urban concentration and occupation of water source areas. The second largest proportion of the total population of Brazil with 5.91\% is the Metropolitan Region of Rio de Janeiro, which in 2014 corresponded to 11,973,505 inhabitants (source: IBGE-Brazilian Institute of Geography and Statistics).

Figure 1 highlights the territorial limit of the MRSP and its respective municipalities that occupy an area of 7,946.82 sq. km and an urbanized area of $2209 \mathrm{sq} . \mathrm{km}$, that is, something around 221 thousand blocks. The urbanized area in 2002 was 874 sq. km, and in forty years (1962 - 2002) this area tripled (EMPLASA - São Paulo Metropolitan Planning Company S.A, 2013). 


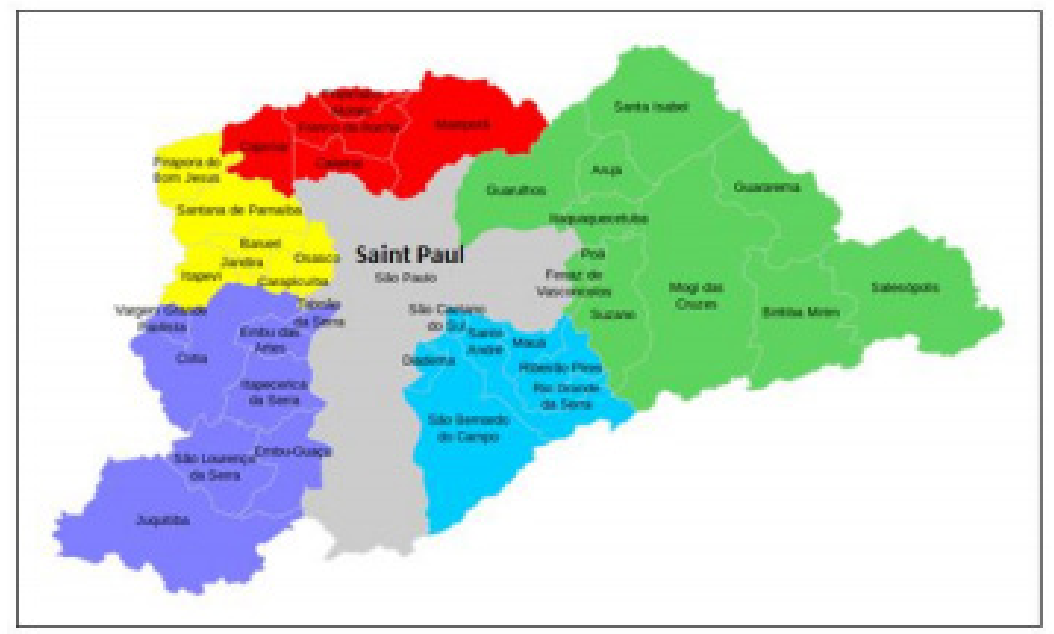

Figure 1 Geopolitical Map of the Metropolitan Region of S ã Paulo Source: City Hall of the municipality of S a Paulo

\section{URBAN SPRAWL OF CITY SÃO PAULO - BRAZIL}

In the 1940s, there was an increase in investment in the industry in São Paulo. With the difficulties imposed by World War II to carry out importation, there was no alternative but to produce the products such as: metallurgical articles to meet the needs of the population and the production of coffee. With this, there was a flow of workers from the interior of the State of São Paulo and other states in search of employment.

The work was easy and well paid, unlike the coffee plantations that had been in decline since the crisis of 1929 with the fall of the New York Stock Exchange (Great Depression). The new inhabitants joined the residents and went to occupy accommodation available at the time. The total of buildings in he city was of 8.642 in 1892 with 120 thousand inhabitants. In 1939, 10,273 buildings were built in São Paulo and in 1942, due to the crisis caused by the Second World War, 7,857 buildings were built. This increased water consumption because people moved into houses and basements of older and less favored regions in terms of water and sewage infrastructure (Victorino, 2002; Witaker, 1946).

Population growth in the downtown area of São Paulo has raised housing costs. The new inhabitants had no alternative but to look for land on the outskirts of the city.

With this type of behavior of people who were looking for work and home to live, there was an expansion of the urban fabric of the city, which is called urban sprawl - when urban growth is deconcentrated, not dense, leaving voids in landscape urban. 
This urban spreading gives way to the peripherization of the population, both the low-income and high-income classes who seek districts farther away from the great center for their dwellings and without urban infrastructure such as running water, sewage and transportation, but cost less compared the downtown area.

The urbanization of a region can be driven by population growth, by failures in the housing policy that can increase or prohibit buildings in certain places, by internal migration with people leaving a municipality or state of one country and going to live in another, by immigration when people leave their country and go to live in another, among others.

Faced with the need for labor for industry and the ease of employment, many workers came to São Paulo and began to occupy the available land spaces and at a lower cost. For this expansion to be successful, even without planning and with all possible negative externalities, there must be a minimum of infrastructure such as: water, transportation, trade of varieties, for example. Therefore, the industrialization, consolidation and integration of the internal market of the urbanization process can not be separated, since they are directly linked.

\section{Table 4 Characteristics the Urban Sprawl of City São Paulo}

\begin{tabular}{|c|c|}
\hline Characteristics & Description \\
\hline $\begin{array}{l}\text { Foundation of the } \\
\text { city }\end{array}$ & $\begin{array}{l}\text { founding - January } 25,1554 \text { by Jesuits Manuel da Nöbrega and Jos é de Anchieta, } \\
\text { Subsistence farming without production or trade structure }\end{array}$ \\
\hline Economic cycles & $\begin{array}{l}\text { Between } 1554 \text { and } 1850 \text {, the economic structure is formed by the economic cycle of } \\
\text { sugar cane, coffee, gold. }\end{array}$ \\
\hline $\begin{array}{l}1850 \text { s and early } 20 \text { th } \\
\text { century }\end{array}$ & $\begin{array}{l}\text { 1) production and export of coffee production in the mid-1850s and early } 20 \text { th century } \\
2 \text { ) industrialization due to the decline of the coffee economy and the need for coffee } \\
\text { growers to maintain their incomes with industries based on small metallurgies. Italian } \\
\text { immigrants, Germans, Japanese, Poles came to work in the industry and in the planting } \\
\text { of coffee, corn, rice. }\end{array}$ \\
\hline $\begin{array}{l}\text { Urbanization } \\
\text { process - }\end{array}$ & $\begin{array}{l}\text { Cost of housing and lack of land in the city center: urban occupation made illegally in } \\
\text { small Ground, slums and precarious tenements (often dangerous or unsanitary). }\end{array}$ \\
\hline $\begin{array}{l}\text { Urbanization } \\
\text { process - } 1970 \text { s - } \\
2010\end{array}$ & $\begin{array}{l}\text { Within a radius of } 20 \text { kilometers from the center of the city, the land becomes more } \\
\text { expensive after the first period of urbanization. The poorest and the newcomers were } \\
\text { now unable to purchase their lot and build their house, and were forced to look for } \\
\text { alternative housing. }\end{array}$ \\
\hline $\begin{array}{l}\text { The impacts of } \\
\text { sprawl }\end{array}$ & $\begin{array}{l}\text { Higher rates of driving and vehicle ownership, Increased levels of pollution, Greater risk } \\
\text { of fatal crashes, Depressed rates of walking and alternative transport use. }\end{array}$ \\
\hline
\end{tabular}
Source: elaborated by authors

The difference between the process of urbanization the São Paulo and the major cities of Europe or the United States is the occupation by immigrants who sought a better life and took advantage of the growth momentum of an economic cycle (coffee, cocoa, sugar, gold). When they reached their goal they returned to their country of origin.

The end of the economic growth of each cycle and the return of the immigrants with the wealth obtained in São Paulo during the two periods of colonization (1500 - 1822 and second period $1822-1889)$, there were no resources for investments. With the industrialization period around 1900, the effects of the two world wars and the new immigrants, the urbanization process of São Paulo is very similar the process of other cities in the world.

The Metropolitan Area of São Paulo (MSRP) in 2005 it had 19 million inhabitants and in 2014 reached a total of 20,935,204 inhabitants representing $10.32 \%$ of the total population of Brazil. The 2016 population of the city of São Paulo: 12.04 million and the metropolitan region with 20.60 million (table 5). 
Table 5 Total Urban and Rural Inhabitants in the MRSP from 2012 to 2016

\begin{tabular}{ccccc}
\hline Year & Population & Urban Population & Rural Population & Percentage of Urbanization \\
\hline $\mathbf{2 0 1 2}$ & 19.973 .125 & 19.747 .066 & 226.059 & 98,87 \\
$\mathbf{2 0 1 3}$ & 20.128 .227 & 19.901 .514 & 226.713 & 98,87 \\
$\mathbf{2 0 1 4}$ & 20.284 .891 & 20.057 .490 & 227.401 & 98,88 \\
$\mathbf{2 0 1 5}$ & 20.443 .152 & 20.215 .028 & 228.124 & 98,88 \\
$\mathbf{2 0 1 6}$ & 20.579 .717 & 20.351 .125 & 228.592 & 98,89 \\
\hline
\end{tabular}

Source: Prepared by authors based on Seade, 2016 (http:/www.imp.seade.gov.br/frontend/\#/tabelas)

Table 5 shows that in 2016 the percentage of urbanization is close to $100 \%$ of the population because urban sprawl transforms the regions farthest from the center of the city into urban areas. With this phenomenon, the impacts of sprawl of table 2 are the same in São Paulo: higher rates of driving and vehicle ownership, increased levels of pollution, greater risk of fatal crashes, depressed rates of walking and alternative transport use.

Considering the distance between the neighborhoods and the size of the municipality of São Paulo $\left(1,521 \mathrm{~km}^{2}\right)$, it practically forces the residents of neighborhoods more distant from the great center (where the jobs are) to driving and vehicle ownership.

A resident in the far east of the city working in the far south should travel 80 kilometers (128.75 miles) and travel time by public transport of one hour and forty minutes if there is no traffic. With these data the choice is by the particular vehicle even if it has larger travel time because of the traffic.

\section{CONCLUSION}

Urban sprawl is a natural process of the city's growth as consequence population growth. The population need a food, water and housing for survival and for its species to continue populating the land. The difference between the growth rates of people and of the land they occupy defines urban sprawl and the single greatest source of wealth creation in history has been the conversion of rural land into urban land - urbanization (Gurin, 2003).

Sprawling communities are a major contributor to climate change and air pollution. The literature existing about urban sprawl considers a population growth causes impacts on people's quality of life because they consume more food, water, electricity, transport for their locomotion, and other products and services. Sprawl is the process in which the spread of development across the landscape far outpaces population growth.

Urban sprawl and consequences of poorly managed expansion the city São Paulo Brazil was no different from other major urban centers around the world. Especially in the twentieth century when industrialization was more, intense with the arrival of immigrants from various parts of the world and the urbanization process - 1970s - 2010 (table 4) when the land became scarcer and very expensive within a radius of twenty kilometers. Conclusion: not only does sprawl contribute to climate change, it consumes large quantities of land, segregates houses from shops and workplaces, depends on private cars, and has little regard for the natural environment (Gurin, 2003). 
Public authorities are taking steps to prevent people living far from large centers from moving and eventually overloading traffic. In 1997, was implanted in the center of the city of São Paulo and later expanded to other regions within a radius of 15 kilometers on average.

The vehicles (private cars and trucks) are prohibited from traveling according to the day of the week and the final number. The plaque which is composed of three letters and four numbers in order to comply with the registration of the vehicles of a fleet of 27.8 million vehicles (including Motorcycles, trucks and buses and agricultural vehicles, which corresponds to $1 / 3$ of the national fleet), of which 17.6 million are passenger cars $(63 \%)$.

The prohibition of circulation of two numbers of end of plate in a day of the week did not generate the expected effect that was to reduce the traffic and the indices of pollution. To approve the traffic ban and not displease the population, public officials said that this would improve air quality because the major source of pollution was the gases from the vehicles.

Another initiative to contribute to reducing the impacts of urban sprawl in São Paulo is Rede Nossa São Paulo - http://www.nossaSãopaulo.org.br/institucional. The movement aims to strengthen the articulation of a broad social field for common objectives and, at the same time, preserve the maintenance of differences for specific, conjunctural, regional, and other issues.

Calling the attention to the problems and challenges on traffic in big cities, Rede Nossa São Paulo is one of the organizers of the World free-day car since 2007.

The mobilization of the World Free-day Car envisages helping urban mobility to ease the problems caused by the "automobile culturell embodied in our routine, and shows that individual transportation is an option that the public administrators, and also the society, need to reconsider.

The city of São Paulo with an area of 1,521 km2, in 2017 the fleet of vehicles in 2017 will reach 6 million. To mitigate negative impacts, policies must be adopted to improve urban mobility. The initiative - free-day car - cooperates with the discussion about the mobility concept that serves as starting point for discussing the inequality, urban planning, health, environment, among others.

Another mobility option implemented in São Paulo was the bike path with the creation of Law 14,266 of February 6, 2007. A bicycle lane (or cycle lane) is a space specifically designed for the movement of people using bicycles. The total length of bike lanes in the city is 323 kilometers (519.82 miles) is expected to reach 400 kilometers (643.88 miles) by the end of 2017.

To give an idea of the territorial extension of the city, the Rio Pinero's Cycle Route is the most extensive. The bike path located in São Paulo, on the eastern bank of the Pinero's River, running parallel to a stretch of Line 9 of the São Paulo Metropolitan Train Company (CPTM). Currently, it has a $21.2 \mathrm{~km}$ extension (34.13 miles), thus being the largest cycle route in the metropolitan region of São Paulo and covering almost the entire length of the Pinero's River. It is an alternative to daily locomotion and leisure option.

The problems with poor management in the occupation of the city are still aggravated by the population growth in all regions of the city. Problems with the increase in accidents, congestion, increased travel time, air pollution and noise, increased cost with vehicle insurance, more expensive maintenance of vehicles, increased costs with the treatment of respiratory diseases, among others. Not is different from other cities in the world (table 2). 


\section{REFERENCES}

[1] Alonso, William. Location and Land Use[M]. Cambridge: Havard University Press, 1964

[2] Ewing, Reid., PENDALL, Rolf., CHEN, Don. [M]. Measuring Sprawl and Its Impact. Washington D.C., 2000

[3] Fair Democratic and Sustainable Cities[M]. Rede Nossa São Paulo, 2016

[4] Glaeser, Edward L., KAHN, Matthew E. Sprawl and Urban Growth[J]. Handbook of Urban and Regional Economics. Volume IV, 2003

[5] Gurin, David. Understanding Sprawl[M]. Vancouver, BC, Canada: The David Suzuki Foundation, 2003

[6] Macrometropole Paulista: Reading of The Territory[R]. EMPLASA - Paulista Company of Metropolitan Planning S.A., 2013

[7] Matos, Guilherme Morávia Soares de[M]. The von Thünen Model: An Application Computational. PUC - Pontifícia Universidade Católica de Minas Gerais: Dissertation presented to the Postgraduate Program in Geography, 2005

[8] Nechyba, Thomas J., WALSH, Randall P.[J]. Urban Sprawl. Journal of Economic Perspectives, 2004,18(4):177-200

[9] Rahman, Muhammad Tauhidur. Detection of Land Use/Land Cover Changes and Urban Sprawl in Al-Khobar, Saudi Arabia: An Analysis of Multi-Temporal Remote Sensing Data[J]. ISPRS - International Journal of Geo-Information Int, 2016,(10)

[10] Singer, Paul. Migraciones internas: consideraciones teóricas sobre su estúdio[M]. México: Comisión de Derechos Humanos del Estado de México (CODHEM). Doctrina 51, 2003 
[11] Stiglitz, Joseph E., SEN, Amartya., FITOUSSI, Rapport de la Commission sur la mesure desperformances économiques et du progrès social[M]. France: INSEE - Institut National de lastatistique et des études économiques, Septembre, 2015

[12] Torrens, Paul M.; ALBERTI, Marina. Measuring Sprawl[M]. University College London: CASA - Centre for Advanced Spatial Analysis, Working Paper Series, 2000:27

[13] VICTORINO, Valério Igor P. A Historical Overview of Water Resources in the City of São Paulo[J].RBRH - Brazilian Journal of Water Resources, 2002,7(1):51-68

[14] Wicksell, Knut. The Influence of the Rate of Interest on Prices[J]. Liberty Fund, 2001

[15] Whitaker, Plínio Penteado. "Water supply in the city of São Paulo" [M]. In: Bulletin of the Water and Sewerage Division, 1946. 